Received 28.09.2018

Reviewed 28.12.2018

Accepted 23.01.2019

A - study design

B - data collection

C - statistical analysis

D - data interpretation

$\mathbf{E}$ - manuscript preparation

$\mathbf{F}$ - literature search

\title{
Analysis of distribution of precipitation duration and amounts in Legnica in the period of 1966-2015
}

\author{
Teresa JAKUBCZYK ${ }^{\text {ABCDEF } 凶}$
}

orcid.org/0000-0003-1038-6923; Wrocław University of Environmental and Life Sciences, Department of Mathematics, 50-357 Wrocław, Poland; e-mail: teresa.jakubczyk@upwr.edu.pl

For citation: Jakubczyk T. 2019. Analysis of distribution of precipitation duration and amounts in Legnica in the period of $1966-2015$. Journal of Water and Land Development. No. 41 (IV-VI) p. 69-76. DOI: 10.2478/jwld-2019-0029.

\begin{abstract}
The paper presents the results of analysis of duration of precipitation sequences and the amounts of precipitation in individual sequences in Legnica. The study was aimed at an analysis of potential trends and regularities in atmospheric precipitations over the period of 1966-2015. On their basis a prediction attempt was made for trends in subsequent years. The analysis was made by fitting data to suitable distributions - the Weibull distribution for diurnal sums in sequences and the Pascal distribution for sequence durations, and then by analysing the variation of the particular indices such the mean value, variance and quartiles. The analysis was performed for five six-week periods in a year, from spring to late autumn, analysed in consecutive five-year periods. The trends of the analysed indices, observed over the fifty-year period, are not statistically significant, which indicates stability of precipitation conditions over the last half-century.
\end{abstract}

Key words: analysis of distributions, Mann-Kendall test, precipitation, rainfall conditions, rainfall variability

\section{INTRODUCTION}

Among all the phenomena that have an effect on climate, precipitations are one of the most difficult to describe and analyse. They are dependent on many other factors, such as cloud cover or temperature, and display a high spatial variability [DEGIRMENDŽIĆ et al. 2004; ŻMUDZKA 2009]. Due to their sensitivity to other climate phenomena, and also to their variation in the course of a year, various proposals for the classification of measurements into specific groups appear in the analysis. The proposals range from all the months [BRZEŹNIAK 2009; DEGIRMENDŽIĆ et al. 2004], individual months [CZARNECKA et al. 2012], calendar seasons [BANASZKIEWICZ et al. 2008; BRZEŹNIAK 2009; CZARNECKA et al. 2012], warm and cold half-years [BANASZKIEWICZ et al. 2008; BRZEŹNIAK 2009; CZARNECKA et al. 2012], to entire years [BANASZKIEWICZ et al. 2008; BRZEŹNIAK 2009; DEGIRMENDŽIĆ et al. 2004]. Diurnal precipitations were analysed by, among others, CALOIERO et al. [2016] in the Calabria region in southern Italy. In their study they divided precipitations into catego- ries depending on their diurnal intensity (from light to torrential). Next, they demonstrated that in the course of a year moderate precipitations are dominant. They also demonstrated that the number of less intensive precipitations increases, while there is a decrease in the number of more intensive ones. The variation of annual and monthly precipitations was also studied by WŁODEK et al. [2016]. In the analysed period of 1956-2012 in the Widawa River basin they observed a decreasing number of days with small precipitation $(<1 \mathrm{~mm})$, with a simultaneous increase of the mean diurnal precipitations in a year. Variations of those adopted time intervals, observed on the basis of analyses, displayed various trends in relation to the period under consideration. The authors of the above studies analysed the mean, minimum, maximum, standard deviation, and percentage of annual precipitation, and the coefficients of variation of monthly sums and irregularity of precipitation. Annual and seasonal sums of precipitation were analysed by KIRSCHENSTEIN [2005] in her study. The authors of those studied did not attempt to create models based on probability distributions of those processes. More ad- 
vanced statistical methods were proposed in the studies by BANASZKIEWICZ et al. [2008], OTOP [2010] and JAKUBOWSKI [1985], who analysed the fit of suitable distributions to data. A two-parameter Gamma distribution was applied for the description of the distribution of precipitation amounts in the analysed periods [BANASZKIEWICZ et al. 2008; ОтОР 2010]. That distribution was also analysed in relation to precipitations in a study by VLČEK et al. [2009], and applied directly in analyses conducted by JIANG et al. [2014]. Pascal distribution was used for analysis of the distribution of duration of precipitation sequences by JAKUBOWSKI [1985]. Apart from direct fitting of probability distributions to data, also other approaches are proposed. RAMÍREZ-COBO et al. [2013] and TEIXEIRA-GANDRA et al. [2017] constructed stochastic models based on Markov processes, while MoDARRES, SILVA [2007] and SAYEMUZZAMAN, JHA [2014] used time series in the analysis of seasonal and annual precipitation totals. Trends and tendencies in precipitations, also in correlation with temperature, were studied by MARTINEZ et al. [2012].

Conclusions following from analysis of variation are not unambiguous. In certain cases an increase of diurnal sums of precipitation was observed. It was proved in spring months, for example in the region of Mazury Lake District (BANASZKIEWICZ et al. [2008]) as well as on the territory of Poland in the period 1951-2000 (DEGIRMENDŽıć et al. [2004]), while other studies ([ŻMUDZKA 2009]) did not show any significant trend for the same area and period. Similar differences appeared for other studied seasons of the year. However, a common conclusions for all the researchers studying those phenomena is the fact that the precipitation tendencies, and consequently the climate tendencies, on the territory of Poland undergo changes in time CZARNECKA et al. [2012].

\section{MATERIAL AND METHOD}

In relation to the proposals presented above, in this study an attempt was made at the use of probabilistic methods for the description of changes in the duration of precipitation sequences and of precipitation sums in those sequences in specific time intervals. Models were created on the basis of distributions selected for suitably constructed data groups, and the goodness of fit of the distributions chosen was estimated using Pearson's $\chi^{2}$ test. The 50-year period under analysis was divided into consecutive fiveyear periods for which, in conformance with the selected distributions, the following characteristics were obtained suitably defined mean and variance, and 25, 50 and $75 \%$ quartiles. In certain cases, their analysis permits extrapolation of studied variations. Basing on fitted distributions and on observation of trends of analysed indices, conclusions were formulated concerning the predicted precipitation variation in consecutive years, in terms of precipitation duration and amounts, and periods of precipitation stability and instability in a year. All calculations were made on the basis on language $\mathrm{R}$ tools and in the program Mathematica, Wolfram Research, Inc.

The proposed models were developed for data acquired from the Institute of Meteorology and Water Man- agement - National Research Institute (IMWM-NRI, Pol. Instytut Meteorologii i Gospodarki Wodnej - Państwowy Instytut Badawczy). The measurements were made in Lower Silesia, in Legnica, 51¹2'19'N, 1609'23”E. Legnica is a town with more than 100 thousand inhabitants, without any high-rise buildings, situated at the boundary of two lowlands - Śląsko-Łużycka and Śląska. Two rivers cross the town - the Kaczawa River, a tributary to the Odra River, the Czarna Woda River, which flows into the Kaczawa, and several streams. Legnica is situated in the moderate climate zone. In the period under study the mean annual precipitation was $533 \mathrm{~mm}$, and the mean annual temperature for the reference multi-year period of 19712000 was about $8.836^{\circ} \mathrm{C}$. The largest amount of precipitation is observed in July, the winter months being the driest. The coolest month is January, and the warmest ones - July and August. Figure 1 presents the distribution of monthly sums of precipitation and mean temperatures during a year. The data relate to the reference multi-year period of 19712000 and come from IMWM-NRI. Table 1 shows precipitation totals and numbers of precipitation sequences for individual years. One can observe that although the precipitation sums may differ significantly, the number of precipitation sequences in a year is relatively constant.

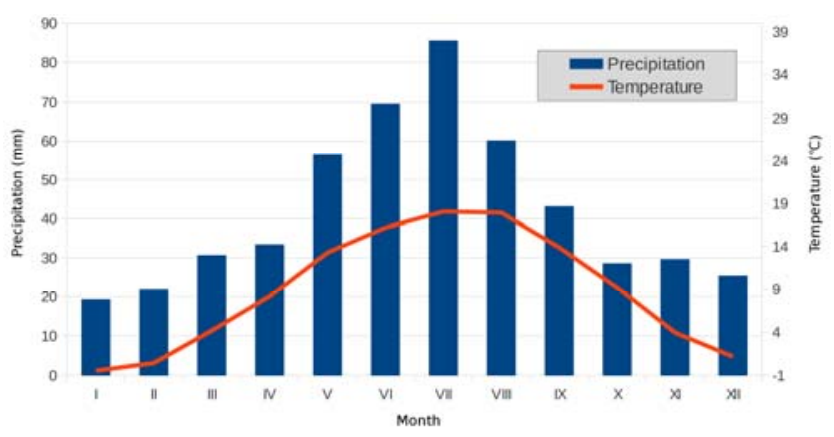

Fig. 1. Mean temperature and monthly sums of precipitation for Legnica in the multi-year period of 1971-2000; source: own elaboration

The precipitation data were analysed in the aspect of two features - the duration of sequences of consecutive days with precipitation, and the sums of precipitation in a given sequence. A single rainless day in the middle of a sequence was treated as a day with trace precipitation - it did not contribute to the precipitation sum, but neither did it interrupt the sequence. Foregoing assumption has been made to separate individual rain sequences. The results of preliminary studies suggested that without cumulation of sequences separated by a single day without precipitation, the independence of subsequent processes could not be stated.

Taking into account the small amount of precipitation data over short time intervals and the fact that due to their high variation precipitation data cannot be analysed over long time periods, and basing on the results of an earlier study (JAKUBOWSKI [1985]), in this study six-week periods were analysed in a year. Five such periods were selected: spring $\left(10^{\text {th }}\right.$ March $-22^{\text {nd }}$ April), late spring (23 ${ }^{\text {rd }}$ April $3^{\text {rd }}$ June), early summer ( $4^{\text {th }}$ June $-17^{\text {th }}$ July), late summer 
Table 1. Annual sums of precipitation and numbers of precipitation sequences in Legnica in analysed years

\begin{tabular}{|c|c|c|}
\hline Year & No. of sequences & Annual sum of precipitation \\
\hline 1966 & 43 & 636.1 \\
\hline 1967 & 37 & 608.4 \\
\hline 1968 & 35 & 606.3 \\
\hline 1969 & 44 & 400.7 \\
\hline 1970 & 40 & 668.1 \\
\hline 1971 & 41 & 492.2 \\
\hline 1972 & 33 & 586.6 \\
\hline 1973 & 41 & 429.4 \\
\hline 1974 & 40 & 632.6 \\
\hline 1975 & 46 & 447.7 \\
\hline 1976 & 43 & 612.1 \\
\hline 1977 & 43 & 795.1 \\
\hline 1978 & 38 & 510.2 \\
\hline 1979 & 47 & 459.1 \\
\hline 1980 & 39 & $\begin{array}{l}581.9 \\
\end{array}$ \\
\hline 1981 & 41 & 670.6 \\
\hline 1982 & 42 & 386.4 \\
\hline 1983 & 47 & 423.6 \\
\hline 1984 & 39 & 420.3 \\
\hline 1985 & 42 & 513.3 \\
\hline 1986 & 44 & 565.1 \\
\hline 1987 & 44 & 563.9 \\
\hline 1988 & 37 & 554.4 \\
\hline 1989 & 43 & 414.5 \\
\hline 1990 & 41 & 407.7 \\
\hline 1991 & 47 & 395.5 \\
\hline 1992 & 47 & 407.6 \\
\hline 1993 & 39 & 512.2 \\
\hline 1994 & 42 & 551.6 \\
\hline 1995 & 35 & 476.5 \\
\hline 1996 & 39 & 464.3 \\
\hline 1997 & 41 & 645.0 \\
\hline 1998 & 40 & 543.3 \\
\hline 1999 & 41 & 477.2 \\
\hline 2000 & 36 & 513.9 \\
\hline 2001 & 41 & 752.3 \\
\hline 2002 & 44 & 520.7 \\
\hline 2003 & 45 & 360.7 \\
\hline 2004 & 41 & 456.2 \\
\hline 2005 & 40 & 495.1 \\
\hline 2006 & 39 & 627.6 \\
\hline 2007 & 36 & 520.6 \\
\hline 2008 & 41 & 474.5 \\
\hline 2009 & 36 & 651.8 \\
\hline 2010 & 40 & 657.8 \\
\hline 2011 & 41 & 578.3 \\
\hline 2012 & 42 & 576.0 \\
\hline 2013 & 42 & 590.0 \\
\hline 2014 & 45 & 508.9 \\
\hline 2015 & 44 & 386.7 \\
\hline
\end{tabular}

Source: own study.

$\left(18^{\text {th }}\right.$ July- $29^{\text {th }}$ August $)$, and autumn $\left(30^{\text {th }}\right.$ August $-11^{\text {th }}$ October). Taking into account dynamic changes in precipitation at the turn of June and July in the last years in the territory of Poland, six-weeks period between June $4^{\text {th }}$ and July $17^{\text {th }}$ was found to be particularly interesting and therefore selected for the study purpose, it was the subject for the first analyses. Inclusion the remaining months into the research, with exception of the winter period, while main- taining a six-week division resulted in the time intervals proposed above. In the case when precipitation occurred at the beginning or end of the analysed period, diurnal sums extending beyond the six weeks chosen were added to the precipitation totals. Rainy days extending beyond the studied period were also added to the sequence duration. In order to simplify the nomenclature the six-weeks periods were named after season which they overlap the most.

Each of the periods defined above was analysed in successive five-year periods (1966-1970, 1971-1975, 1976-1980, 1981-1985, 1986-1990, 1991-1995, 19962000, 2001-2005, 2006-2010, 2011-2015). That way ten independent groups of data were obtained, each of which contained between twenty and thirty observations, both in the case of the sums and the sequence durations. For each of the groups a suitable probability distribution was estimated, based on which further analyses were conducted.

The Weibull distribution was used for the analysis of variation of precipitation sums in sequences. The goodness of fit of the distributions was tested with Pearson's $\chi^{2}$ test. The Gamma distribution, proposed in references (JAKUBOWSKI [1985] and BANASZKIEWICZ et al. [2008]), was also well fitted to data analysed in this study, but based on the Akaike criterion [BOZDOGAN 1978; SNIPES, TAYLOR 2014; WAGENMAKERS, FARREL 2004], it was decided that the data fitted the Weibull distribution better. The density function of the Weibull distribution is expressed as:

$$
f(x, \lambda, k)=\left(\frac{k}{\lambda}\right)\left(\frac{x}{\lambda}\right)^{(k-1)} e^{-\left(\frac{x}{\lambda}\right)^{k}}, x \geq 0
$$

Where: $\lambda=$ scale parameter, $k=$ form parameter, are positive real numbers.

For the description of precipitation sequence duration a negative binomial distribution was applied (according to JAKUBOWSKI [1985]). In this case the probability distribution function has the following form:

$$
f(k, r, p)=\frac{\Gamma(r+k)}{k ! \Gamma(r)} p^{k}(1-p)^{r}, k \in \mathbb{N}
$$

Parameters $r>0$ and $0<p<1$ belong to the set of real numbers.

Basing on the chosen distributions, for each of the analysed periods we determined the mean, variance and the first, second and third degree quartiles for precipitation sums in sequences, and also the mean and variance for sequence durations. This way, for each of the characteristics a ten-element vector of variation over the analysed 50-year period was obtained.

Basing on the studies by JAAGUS et al. [2016], KUNDZEWICZ et al. [2005] and XIONG et al. [2015], to determine the tendencies of the analysed characteristics the Mann-Kendall test was performed on the obtained data groups. That test, in various variants, was also used by ChAtTERJEe et al. [2016], HAMED [2008] and by NemA et al. [2018]. In accordance with the studies by KUNDZEWICZ et al. [2005], RADZIEJEWSKI et al. [2000] and SVENSSON et al. [2005], for the estimation of tendencies an index was applied basing on the $p$-value of the Mann-Kendall test $(\alpha)$. The index was defined as follows: 


$$
T I=\left\{\begin{array}{cc}
1-\alpha \text { for increasing trends } \\
\alpha \text { for decreasing trends }
\end{array}\right.
$$

Customarily, the $T I$ is multiplies by $100 \%$ so that it assumes values from $-100 \%$ to $100 \%$. High positive values of the index suggest increasing trends of the analysed characteristic, and high negative values indicate its decreasing trends in the analysed period. The index allows also to determine the statistical significance of a given trend. For example, a trend is significant at the level of $10 \%$ if $T I \geq 90 \%$ or $T I \leq-90 \%$ [KUNDZEWICZ et al. 2005].

\section{RESULTS AND DISCUSSION}

The Weibull distribution proved to be very well fitted to precipitation sums in sequences - probabilities of goodness of fit of the particular data groups with the Weibull distribution, calculated with the use of the $\chi^{2}$ test, were not lower than 0.05 . Table 2 presents the probabilities of goodness of fit of the distributions for all five-year periods in the individual periods analysed.

A negative binomial distribution describes well the variation of precipitation sequence durations - probabilities of goodness of fit resulting from Pearson's $\chi^{2}$ test were at a satisfactory level, being equal to a higher than 0.05 . The probabilities of goodness of fit for all five-year periods in the individual periods analysed are presented in Table 2. Figures 2 and 3 present an example of fitting the Weibull distribution of precipitation sums in sequences and the Pascal distribution to the duration of precipitation sequences for each of the analysed periods of the five-year period of 1991-1995. Despite that the probabilities of goodness of fit in the chosen period are not the highest among all, one can observe satisfying fitting of the distributions.

Table 2. Results of $\chi^{2}$ test - probabilities of Weibull and Pascal distributions fit to precipitation amounts in sequences

\begin{tabular}{|c|c|c|c|c|c|}
\hline Sequence & Spring & $\begin{array}{c}\text { Late } \\
\text { spring }\end{array}$ & $\begin{array}{c}\text { Early } \\
\text { summer }\end{array}$ & $\begin{array}{c}\text { Late } \\
\text { summer }\end{array}$ & Autumn \\
\hline \multicolumn{5}{|c|}{ Weibull distribution } \\
\hline $1966-1970$ & 0.29 & 0.74 & 0.35 & 0.34 & 0.05 \\
\hline $1971-1975$ & 0.35 & 0.60 & 0.46 & 0.09 & 0.93 \\
\hline $1976-1980$ & 0.56 & 0.33 & 0.08 & 0.18 & 0.80 \\
\hline $1981-1985$ & 0.30 & 0.78 & 0.36 & 0.23 & 0.32 \\
\hline $1986-1990$ & 0.46 & 0.18 & 0.12 & 0.23 & 0.17 \\
\hline $1991-1995$ & 0.19 & 0.35 & 0.09 & 0.22 & 0.53 \\
\hline $1996-2000$ & 0.11 & 0.32 & 0.43 & 0.15 & 0.22 \\
\hline $2001-2005$ & 0.10 & 0.38 & 0.07 & 0.21 & 0.10 \\
\hline $2006-2010$ & 0.05 & 0.46 & 0.49 & 0.60 & 0.55 \\
\hline $2011-2015$ & 0.31 & 0.29 & 0.35 & 0.32 & 0.06 \\
\hline \multicolumn{7}{|c|}{ Pascal distribution } \\
\hline $1966-1970$ & 0.16 & 0.22 & 0.65 & 0.43 & 0.57 \\
\hline $1971-1975$ & 0.53 & 0.44 & 0.24 & 0.37 & 0.59 \\
\hline $1976-1980$ & 0.05 & 0.40 & 0.07 & 0.39 & 0.81 \\
\hline $1981-1985$ & 0.44 & 0.44 & 0.45 & 0.23 & 0.97 \\
\hline $1986-1990$ & 0.05 & 0.51 & 0.59 & 0.53 & 0.09 \\
\hline $1991-1995$ & 0.19 & 0.78 & 0.47 & 0.50 & 0.75 \\
\hline $1996-2000$ & 0.90 & 0.24 & 0.13 & 0.55 & 0.20 \\
\hline $2001-2005$ & 0.73 & 0.13 & 0.23 & 0.26 & 0.40 \\
\hline $2006-2010$ & 0.34 & 0.07 & 0.09 & 0.16 & 0.48 \\
\hline $2011-2015$ & 0.29 & 0.07 & 0.18 & 0.23 & 0.69 \\
\hline
\end{tabular}

Source: own study.
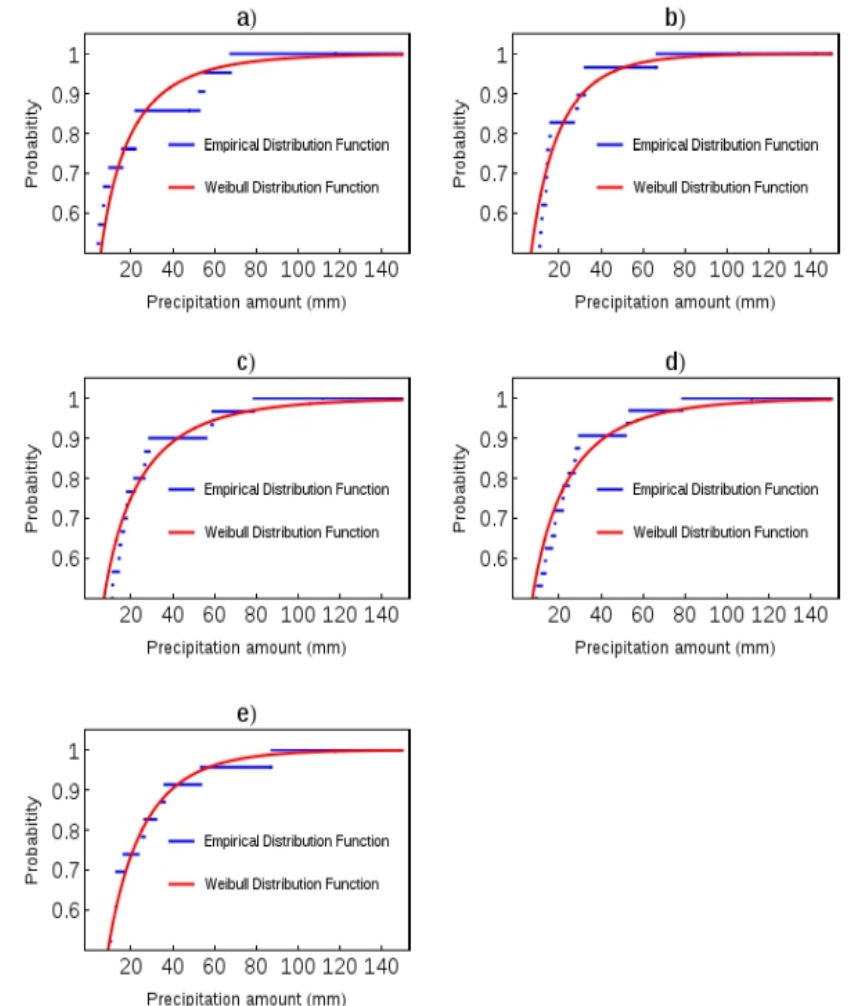

Fig. 2. Fitting of Weibull distribution to precipitation amounts in sequences in the period of 1991-1995: a) spring, b) late spring, c) early summer, d) late summer, e) autumn; source: own study
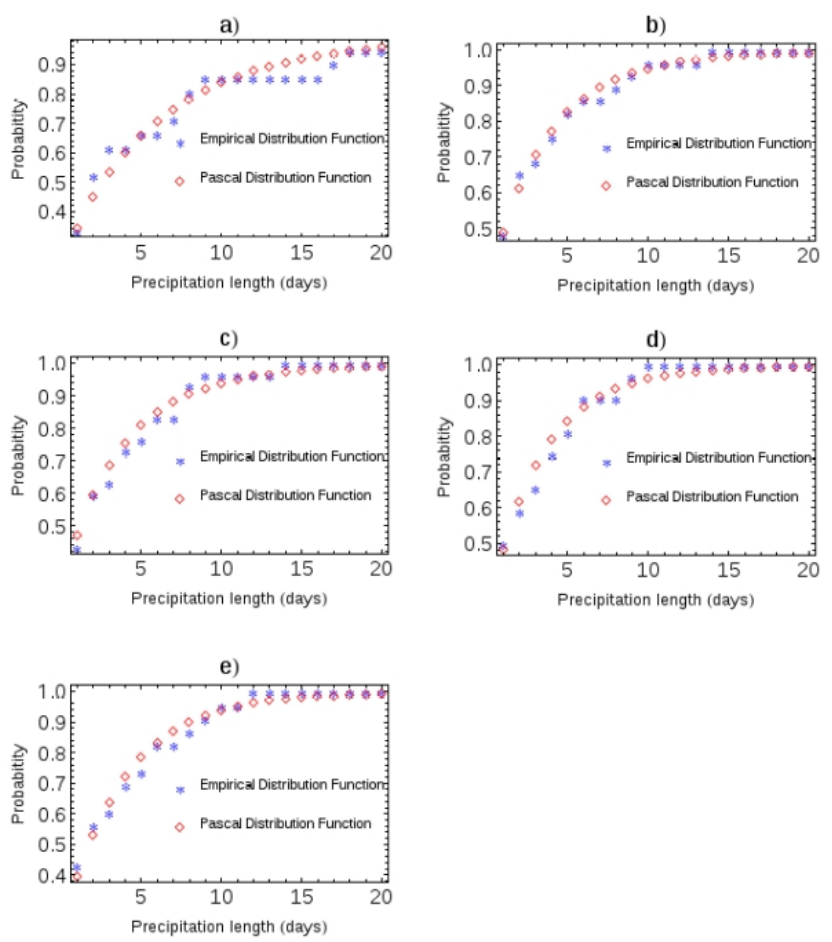

Fig. 3. Fitting of Pascal distribution sequence durations in the period of 1991-1995: a) spring, b) late spring, c) early summer, d) late summer, e) autumn; source: own study 
In consequence of the very good fit of the chosen distributions to the data, an attempt was made at analysing the variation of distributions of precipitation sums in sequences and of precipitation sequence durations in consecutive five-year periods. Approximation of variation of the analysed characteristics, mean, variance and quartiles, was performed using the Mann-Kendall test. Table 3 presents values of $T I$ index for characteristics studied in the analysis of distribution of sequence durations and precipitation amounts in sequences. Attention should be drawn to the fact that none of the identified trends was statistically significant, at the adopted $90 \%$ interval of confidence. We cannot, therefore, reject the hypothesis of a lack of linear trends on the analysed data sets. This conclusion is similar to those formulated in earlier studies. MODARRES, SILVA [2007], TABARI, TALAEE [2011], and SAYEMUZZAMAN, JHA [2014], studying precipitation data from the areas of Iran and North Carolina, observed statistically significant trends, both decreasing and increasing, in specific short several-year periods. However, they did not confirm the existence of an unambiguous decreasing or increasing trend for entire multi-year periods, or for specific periods within a year. Similar conclusion was drawn from the analysis of precipitation data from the area of Poland. According to CZARNECKA et al. [2012], changes in precipitation amounts in multi-year periods do not display any significant linear trends.

Table 3. Percentage trend indices $T I$ in individual periods

\begin{tabular}{|l|c|c|c|c|c|c|c|}
\hline \multirow{2}{*}{$\begin{array}{c}\text { Selected } \\
\text { period }\end{array}$} & \multicolumn{4}{|c|}{ Precipitation amount } & \multicolumn{2}{c|}{$\begin{array}{c}\text { Sequence } \\
\text { duration }\end{array}$} \\
\cline { 2 - 8 } & $\mu$ & $\sigma^{2}$ & $Q_{1}$ & $Q_{2}$ & $Q_{3}$ & $\mu$ & $\sigma^{2}$ \\
\hline Spring & -62.89 & -27.95 & -62.89 & -62.89 & -71.69 & -78.95 & -62.89 \\
\hline $\begin{array}{l}\text { Late } \\
\text { spring }\end{array}$ & -27.95 & 14.20 & -89.26 & -78.95 & -40.85 & 0 & 0 \\
\hline $\begin{array}{l}\text { Early } \\
\text { summer }\end{array}$ & 71.69 & 84.76 & 0 & 14.20 & 40.85 & 27.95 & -40.85 \\
\hline $\begin{array}{l}\text { Late } \\
\text { summer }\end{array}$ & -14.12 & 84.76 & 0 & -14.20 & -14.20 & 62.90 & 27.95 \\
\hline Autumn & 71.69 & 27.95 & 62.89 & 78.95 & 71.69 & 40.85 & -84.76 \\
\hline
\end{tabular}

Explanations: $\mu=$ mean, $\sigma^{2}=$ variance, $Q_{1}=20$-percent quartile, $Q_{2}=50$ -percent quartile, $Q_{3}=75$-percent quartile.

Source: own study.

In view of the absence of statistically significant trends in the precipitation data for the last fifty-year period, we can infer general stability of the precipitation phenomena in the studied area. A similar conclusion appears in the case of direct analysis of parameters of the Weibull and Pascal distributions fitted to data from consecutive ten-year periods in the chosen periods of the year. Although both the precipitation sums in sequences and the sequence durations over the years appear to be fairly varied, the distributions, with minor exceptions, behave in a similar manner. This is illustrated in Figures 4 and 5, relating to the entire fifty-year period under study. The probabilities of occurrence of precipitation with a given amount in each of the analysed periods follow a characteristic pattern over the space of the entire fifty-year period. Irrespective of what happens in the case of small and high precipitations, in each of the chosen periods the probabilities of occurrence

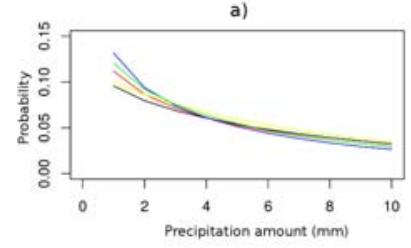

b)
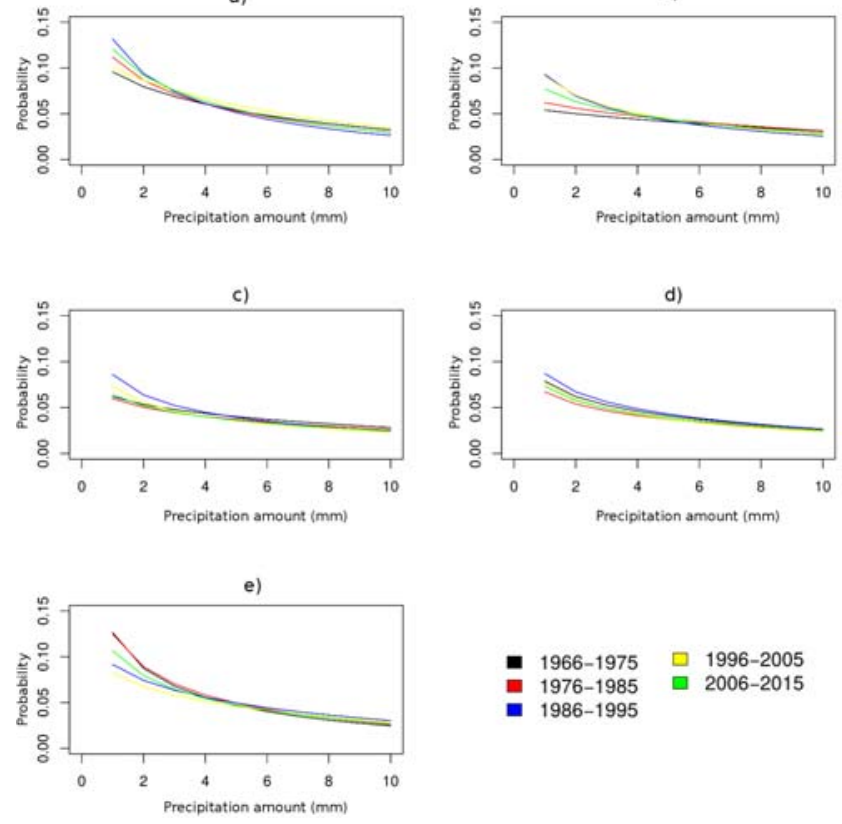

Fig. 4. Weibull distribution for consecutive ten-year periods in analysed seasons of the year: a) spring, b) late spring, c) early summer, d) late summer, e) autumn; source: own study
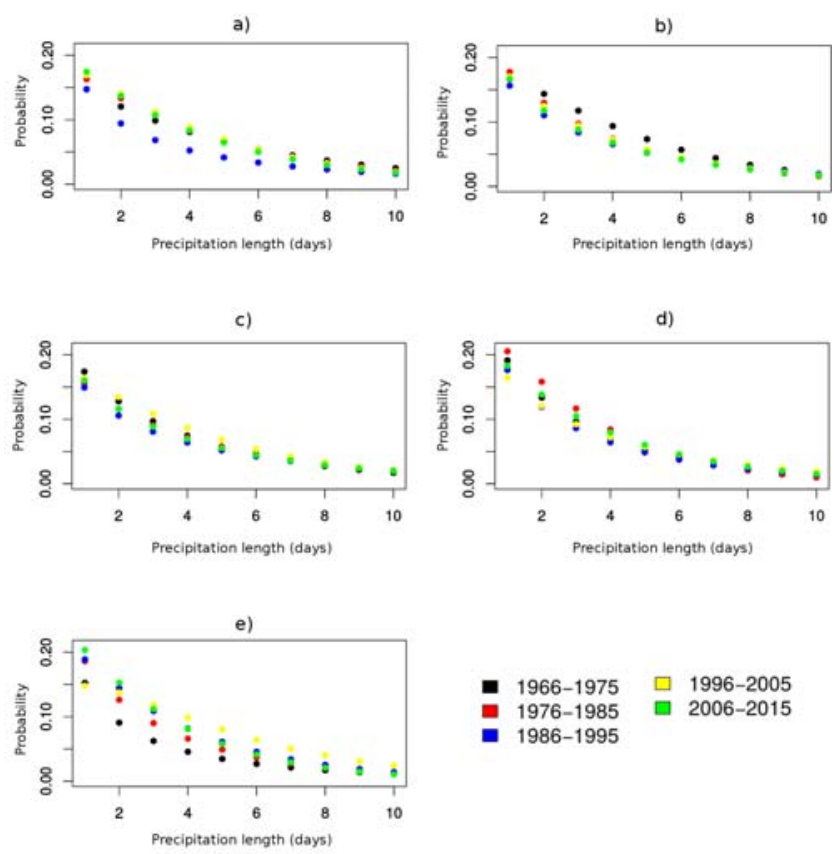

- 1966-1975 $\square$ 1996-2005 1976-1985 $\square$ 2006-2015 1986-1995

Fig. 5. Pascal distribution for consecutive ten-year periods in analysed seasons of the year: a) spring, b) late spring, c) early summer, d) late summer, e) autumn; source: own study

of precipitation amounting to 4-5 are equal, irrespective of the ten-year period under analysis. A slight variation of the probabilities is observed for small precipitations and for short time intervals.

Apart from the analysis of the distribution parameters, an attempt was also made at analysing simple time series represented by five- and fifteen-year moving averages of the mean diurnal precipitation in a sequence. In all the years, for each of the analysed periods, the mean diurnal 
precipitation in a sequence was calculated by dividing the precipitation sum of the period by the sum of the sequence durations that occurred in that time. Due to the high variation of the five-year average in time, the analysis of variation was conducted by comparing it to the fifteen-year average. Observations of the five- and fifteen-year moving averages allow to formulate a conclusion on cyclic changes of the analysed characteristics. However, the cycles are not regular, and they have different lengths for each of the analysed periods. The five- and fifteen-year moving averages are presented in Figure 6. The broken lines superimposed on the graphs represent trends of changes of the moving averages in the fifty-year period under analysis.

The common point for the analysed six-week periods is the period ending the analysed fifty-year period, i.e. what happens after the year 2010. In each case the fiveyear average of precipitation sum has then an increasing trend, and apart from early summer it is higher than the fifteen-year average. In early summer it remains in the increasing trend, while for the remaining periods it decreases, and apart from the late summer period remains at a high level. The differences between five- and fifteen-year averages after the year 2010 indicate possible changes in

tendencies of the precipitations, observed before in spring season by, among others, BANASZKIEWICZ et al. [2008] and DEGIRMENDŽIĆ et al. [2004], and in spring and autumn by CZARNECKA et al. [2012].

Analysing the behaviour of the five-year average relative to the fifteen-year average over the entire fifty-year period, in specific periods one can observe characteristic oscillations and different trends of the averages.

The spring period is characterised by small and irregular oscillations of the five-year average sum of precipitation around the fifteen-year average. The most noticeable is the increase of the average sum of precipitation around the year 1980, followed by a decrease in the years 19952005. The fifteen-year average remains at a constant level.

In late spring was can observe regular oscillations of the five-year average around the fifteen-year average in more or less ten-year cycles. The most observable is the increase of the average after 1980 and its decrease after 1990. The fifteen-year average remains at a constant level, without any greater deviations.

In early summer one can observe two characteristic periods. Until 1995 the precipitation averages decrease systematically. Then the trend reverses, both in the case of the five- and the fifteen-year
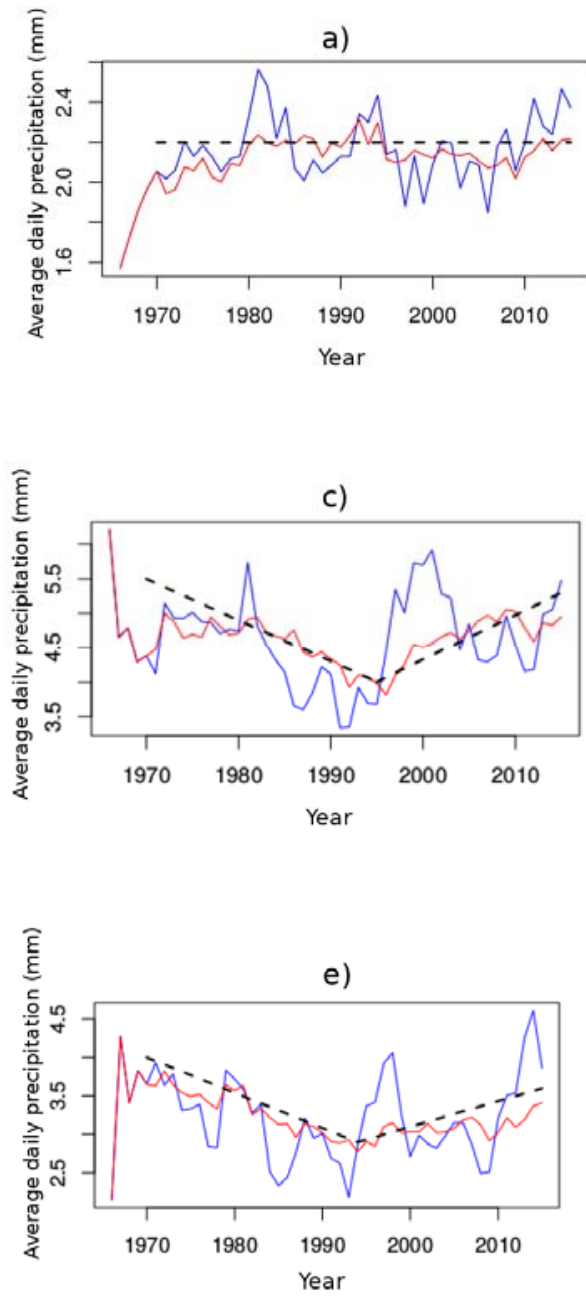

Fig. 6. Five- and fifteen-year moving averages of mean precipitation sums in consecutive analysed periods in a year: a) spring, b) late spring, c) early summer, d) late summer, e) autumn; source: own study average. The most distinc-
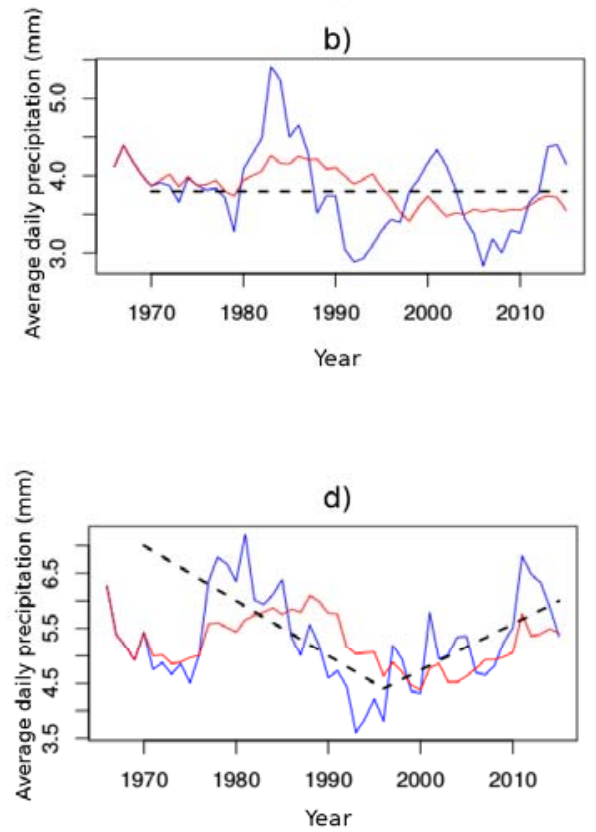

tive in the entire fifty-year period is the ten-year period of 1995-2005, when the five-year average is significantly higher than the fifteen-year average. That period includes the year of the 1997 Central European flood.

In the period of late summer both averages display decreasing trends, until 1995, after which there is an increase of the fiveyear average. In the period of 1985-1997 the five-year average of precipitation sums is lower than the fifteen-year average. In the other periods it remains above the fifteen-year average, or becomes equal to it.

In autumn the oscillations of the five-year average form cycles of 7-10 years. Until 1994 there are distinct deepening decreases of the five-year average, followed by increasingly high increments in the years 1994-2000 and after 2010.

In the final three analysed periods (early sum- 
mer, late summer and autumn) there is characteristic behaviour of the moving averages. From the beginning of the analysed period they have a decreasing trend which gets reversed after 1995.

\section{SUMMARY AND CONCLUSIONS}

1. In each of the analysed six-week periods a slight variation of distributions fitted to the data is observed, both with regard to the precipitation sums in sequences and to the duration of precipitation sequences. Such behaviour of the distributions indicates precipitation phenomena stability over the fifty-year period under study. Trends in precipitation amounts and sequence durations observed over the fifty-year period under study are not statistically significant. Therefore, we cannot reject the hypothesis of the lack of unambiguous increasing or decreasing linear trends in the data sets. One can infer that there is a general precipitation stability in the area under study, despite the high natural variability of precipitation.

2. The analysis of simple time series, five- and fifteenyear moving averages of precipitation sums in the sequences, revealed the existence of cyclic changes in precipitation intensity. In each of the analysed periods the cycles are of different and variable length, varying from five to about twelve years.

3. Characteristic of the end of the analysed fifty-year period, in each of the six-week periods under analysis, is a higher value of the five-year average than the fifteen-year average. This suggests a higher precipitation intensity in the years after 2015 .

4. Two groups can be identified in the analysed sixweek periods. The spring and late spring are stabilised, with the five- and fifteen year averages remaining on a constant level. In early and late summer and in autumn both averages display decreasing trends, and after the year 1995 they change their character.

\section{REFERENCES}

BANASZKIEWICZ B., GrabowsKa K., SZWEJKOWSKi Z. 2008. Characterization of variability of atmospheric precipitation at selected stations of the Mazury Lake district in the years 1951-2000. Acta Agrophysica. No. 12(1) p. 19-27.

BozDogAN H. 1978. Model selection and Akaike's Information Criterion (AIC): The general theory and its analytical extensions. Psychometrika. Vol. 52. Iss. 3 p. 345-370.

BRZEŹNIAK E. 2009. Struktura czasowa opadów atmosferycznych w Ojcowie [Times structure of precipitation in Ojców]. Prądnik. Prace Muzeum Szafera. Vol. 19 p. 53-66.

Caloiero T., Coscarelli R., Ferrari E., Sirangelo B. 2016. Trends in the daily precipitation categories of Calabria (southern Italy). Procedia Engineering. Vol. 162 p. 32-38.

Chatterjee S., Khan A., Akbari H., Wang Y. 2016. Monotonic trends in spatiotemporal distribution and concentration of monsoon precipitation (1901-2002), West Bengal, India. Atmospheric Research. No. 182 p. 54-75.

CZARneCKa M., NidZGORSKA-LENCEWICZ J. 2012. Wieloletnia zmienność sezonowych opadów w Polsce [Multiannual variability of the seasonal precipitation in Poland]. WodaŚrodowisko-Obszary Wiejskie. T. 12. Z. 2 (38) p. 45-60.
DEGIRMENDŽIĆ J., KoŻUChOWSKI K., ŻMUDZKA E. 2004. Changes of air temperature and precipitation in Poland in the period 1951-2000 and their relationship to atmospheric circulation. International Journal of Climatology. No. 24 p. 291-310.

HAMED K.H. 2008. Trend detection in hydrologic data: The Mann-Kendall trend test under the scaling hypothesis. Journal of Hydrology. Vol. 349. Iss. 3-4 p. 350-363.

JaAgus J., BRIEDE A., Rikmus E., SePP M. 2016. Changes in precipitation regime in the Baltic countries in 1966-2015. Theoretical and Applied Climatology. Vol. 131. Iss. 1-2 p. 433443.

JAKUBOWSKI W. 1985. Prognoza procesu występowania opadów atmosferycznych [Prognosis of the process of occurrence of precipitation]. PhD thesis. Wrocław. AR.

Jiang Z., Shen Y., Ma T., Zhai P., Fang S. 2014. Changes of precipitation intensity spectra in different regions of mainland China during 1961-2006. Journal of Meteorological Research. Vol. 28. Iss. 6 p. 1085-1098.

KIRSCHENSTEIN M. 2005. Wieloletnie zmiany sum opadów atmosferycznych na wybranych stacjach północno-zachodniej Polski [Multiannual changes of the sums of precipitations on the chosen stations of the north-western Poland]. Słupskie Prace Geograficzne. Vol. 2. p. 199-214.

Kundzewicz Z.W., GraczyK D., Maurer T., Pińskwar I., RAdZieJewski M., Svensson C., Szwed M. 2005. Trend detection in river flow series: 1 . Annual maximum flow. Hydrological Sciences Journal. Vol. 50. Iss. 5 p. 797-810.

Martinez C.J., MALESKi J.J., MilleR M.F. 2012. Trends in precipitation and temperature in Florida, USA. Journal of Hydrology. Vol. 452-453 p. 259-281.

ModarRes R., Silva V. 2007. Rainfall trends in arid and semiarid regions of Iran. Journal of Arid Environments. Vol. 70. Iss. 2 p. $344-355$.

Nema M.K., Khare D., Adamowski J., Chandniha S.K. 2018. Spatio-temporal analysis of rainfall trends in Chhattisgarh State, Central India over the last 115 years. Journal of Water and Land Development. No. 36 p. 117-128. DOI 10.2478/ jwld-2018-0012.

ОтоР I. 2010. Precipitation variability in the middle Odra river basin in the years 1951-2005. Acta Agrophysica. Vol. 4(183) p. $50-59$.

RADZIEJEWSKi M., BARdossy A., KunDZEWICZ Z.W. 2000. Detection of change in river flow using phase randomization. Hydrological Sciences Journal. Vol. 45. Iss. 4 p. 547-558.

Ramírez-Cobo P., Marzo X., Olivares-Nadal A.V., Álvarez Francoso J., Carrizosa E., Fernanda Pita M. 2013. The Markovian arrival process: A statistical model for daily precipitation amounts. Journal of Hydrology. Vol. 510 p. 459471.

SAYEMUZZAMAN M., JHA M.K. 2014. Seasonal and annual precipitation time series trend analysis in North Carolina, United States. Atmospheric Research. Vol. 137 p. 183-194.

SNIPES M., TAYLOR D.C. 2014. Model selection and Akaike information criteria: An example from wine ratings and prices. Wine Economics and Policy. Vol. 3. Iss. 1 p. 3-9.

Svensson C., Kundzewicz Z.W., MAurer T. 2005. Trend detection in river flow series: 2 . Flood and low-flow index series. Hydrological Sciences Journal. Vol. 50. Iss. 5 p. 811-824.

TABARI H., TALAEE P.H. 2011. Temporal variability of precipitation over Iran: 1966-2005. Journal of Hydrology. Vol. 396. Iss. 3-4 p. 313-320.

TeIXeIRA-GANDRA C., DAmÉ R., Silva G. 2017. Stochastic modeling using Markov chain on the forecast standardized precipitation index. Científica. Vol. 45. No 2 p. 137-144.

VlČEK O., HUTH R. 2009. Is daily precipitation Gamma-distributed? Adverse effects of an incorrect use of the KolmogorovSmirnov test. Atmospheric Research. Vol. 93 p. 759-766. 
WAGENMAKERS E-J., FARREL S. 2004. AIC model selection using Akaike weights. Psychonomic Bulletin and Review. Vol. 11. Iss. 1 p. 192-196.

WŁodek S., Pawęska K., Biskupski A., Sikora J., SeKutowski T.R., MAGA J., JAKUBOWSKI T. 2016. Precipitation variation in the Widawa river basin in the multi-year period 19562012. Infrastructure and Ecology in Rural Areas. No. IV/4 p. 1947-1959.
Xiong L., Du T., Xu C-Y., Guo S., Jiang C., GipPel C.J. 2015. Non-stationary annual maximum flood frequency analysis using the norming constants method to consider non-stationarity in the annual daily flow series. Water Resources Management. Vol. 29. Iss. 10 p. 3615-3633.

ŻMUDZKa E. 2009. Współczesne zmiany klimatu Polski [Contemporary changes of the climate of Poland]. Acta Agrophysica. No. 13(2) p. 555-568.

\section{Teresa JAKUBCZYK}

\section{Analiza rozkładów długości trwania i wielkości opadów w Legnicy w latach 1966-2015}

\section{STRESZCZENIE}

W pracy przedstawiono wyniki analiz rozkładów długości trwania sekwencji opadowych oraz wielkości opadów w poszczególnych sekwencjach w Legnicy. Badania miały na celu przeprowadzenie analizy ewentualnych tendencji i regularności w opadach atmosferycznych w okresie 1966-2015. Na ich podstawie podjęto próbę predykcji dla tendencji w kolejnych latach. Analizę wykonano przez dopasowanie do danych odpowiednich rozkładów - rozkładu Weibulla do sum dobowych w sekwencjach oraz rozkładu Pascala do długości sekwencji, a następnie przez zbadanie zmienności poszczególnych wskaźników, takich jak średnia, wariancja i kwartyle. Analiza została przeprowadzona w odniesieniu do pięciu sześciotygodniowych okresów w ciągu roku od wczesnej wiosny do późnej jesieni, rozpatrywanych w kolejnych pięcioleciach. Tendencje badanych wskaźników zaobserwowane na przestrzeni pięćdziesięciolecia nie są istotne statystycznie, co świadczy o stabilności zjawiska opadów w ostatnim pięćdziesięcioleciu.

Słowa kluczowe: analiza rozkładów, opady, test Manna-Kendalla, warunki opadowe, zmienność opadów 